\title{
AOR
}

Selected Papers of \#AolR2019:

The $20^{\text {th }}$ Annual Conference of the Association of Internet Researchers Brisbane, Australia / 2-5 October 2019

\section{“ALEXA, CAN I TRUST YOU?”: SMALL SISTERS AND FRIENDLY POWER}

Luke Munn

Institute for Culture \& Society, Western Sydney University

How is trust fabricated today? This paper argues that the persona of 'Alexa' bypasses concerns around surveillance and privacy, defusing anxieties not via the rationality of a convincing argument but through the relationality of Alexa as a singular presence. Always listening and empathically attuned, she embodies a turn toward "friendly power" (Han 2017). Rather than Big Brother, she is experienced as a small sister.

Alexa is typically described as a voice-based virtual assistant. Once her wake-word of 'Alexa' is uttered, she listens to a user's voice, parsing it into text and responding by playing music, setting timers, dimming lights, or ordering products. Alexa has now expanded to power a whole ecosystem of products, from thermostats and baby monitors to car interfaces. Indeed, Amazon recently revealed that 100 million of these 'Alexa-enabled' devices have been sold (Bohn 2019). Moreover, there are over 10,000 employees working on the Alexa team (Macmillan 2018). These figures are not about parroting a Silicon Valley success story, but about considering her widespread adoption from the perspective of power. Why do so many feel they can trust Alexa?

In many respects Alexa is more invasive than other technologies. By placing these assistants in the living room or kitchen, Amazon has encroached into the very heart of the home. In addition, the company is actively seeking to delve further into the subject through voice identification, mood monitoring, and health detection. Every day Amazon extracts an immense amount of conversational data and funnels it to their data centers, where it can be mined for consumer insights and trained on via machine learning in order to develop more sophisticated systems. "There are millions of these in households, and they're not collecting dust" admitted one Alexa team member, "we get an insane amount of data coming in that we can work on" (Simonite 2017).

But, based on my PhD research involving ethnography, technical and discourse analysis, this paper argues that Alexa feels different-in fact, she instrumentalizes feeling itself. After combing through logs, one Amazon developer was surprised to find Suggested Citation (APA): Munn, L. (2019, October 2-5). "Alexa, Can I Trust You?": Small Sisters and Friendly Power. Paper presented at AoIR 2019: The 20th Annual Conference of the Association of Internet Researchers. Brisbane, Australia: AolR. Retrieved from http://spir.aoir.org. 


\section{AOR}

Selected Papers of \#AolR2019: The $20^{\text {th }}$ Annual Conference of the Association of Internet Researchers Brisbane, Australia / 2-5 October 2019

that "every day, hundreds of thousands of people say 'good morning' to Alexa" (Turk 2016). Another user admitted that "I have a very familiar relationship with my Echo. I talk to it like it's an actual person" (Schwedel 2016). Such treatment is by design. As one study observed (Purington et al. 2017), Alexa is endowed with a name and gender, she can interact playfully, she is co-located with users, and she can alter the environment-all of which "are designed to afford social functionalities and promote anthropomorphism." Rather than an algorithmic bundle of technologies, Alexa is experienced as an affective persona.

The goal is to make this persona warm and welcoming, affirmative and open. Product Chief Tony Reid has said the team's aim is to develop something that is friendly, can turn off your lights, chat about anything, and empathize when you're having a bad day (McGirt 2018). Alexa has now added an ability to distinguish between voices. Rather than 'zeroed out' for a generic user after each use, this capability allows for ongoing relationships ('from our last conversation, I recall that'). Moreover, recent patents attempt to delve further into the life of the individual, detecting vocal variations that betray one's present health condition and current mood. Thus, while Amazon is constantly updating her capacities, the overall vector remains the same: to develop something chattier and chummier, something more affective and emotionally attuned. In doing so, Alexa embodies what theorist Byung-Chul Han has called "friendly power." Such power operates not through restrictive obedience, but via relentless affirmation. As Han asserts $(2017,36)$ : 'It says 'yes' more often than 'no'; it operates seductively, not repressively. It seeks to call forth positive emotions and exploit them." Rather than remaining at a distance, it "cosies up to the psyche" (2017 37). Always attentive and always supportive, Alexa remains structurally open to every utterance.

The result, then, is a strange paradox. On the one hand, Amazon has actually become more invasive, capturing conversational data from the kitchens and living rooms of millions homes while actively developing new ways to extract intimate information about health, mood, daily routines, and so on. Yet at the same time, judging by consumers' embrace of Alexa, trust has also been increased. While concerns around privacy or data use have surfaced in a handful of articles, they have never gained significant traction, particularly when compared against technologies like Facebook. The paper thus argues that, even as voices are extracted and data is mined, the persona of Alexa produces a subjective shift that has a substantive impact on the issue of trust. Alexa

Suggested Citation (APA): Munn, L. (2019, October 2-5). "Alexa, Can I Trust You?": Small Sisters and Friendly Power. Paper presented at AoIR 2019: The 20th Annual Conference of the Association of Internet Researchers. Brisbane, Australia: AolR. Retrieved from http://spir.aoir.org. 


\section{AOR}

Selected Papers of \#AolR2019:

The $20^{\text {th }}$ Annual Conference of the Association of Internet Researchers Brisbane, Australia / 2-5 October 2019

isn't monitoring you, she's getting to know you. Alexa isn't recording you, she's listening to you. And Alexa isn't advertising to you, she's conversing with you. Capture is reframed as companionship.

Alexa thus accomplishes a double move, delving deeper into the inner life of the subject, while simultaneously shrugging off the anxieties associated with cold, command-and-control technologies. Such force, at once lighter and more penetrative, suggests a gap in theorizations of power. If the notion of Big Brother does not adequately characterize contemporary power (Harcourt 2015), then Alexa might be labeled as a "small sister." Rather than an all-seeing eye, she is an always listening voice. Rather than an awe-inspiring dictator, she is a friendly companion. And rather than emanating from a central agency, she is distributed throughout millions of homes and co-located with the user. Small sisters work alongside instead of above, developing an intimate understanding of subjects and fulfilling or even anticipating their needs. In contrast to power as centralized and spoken from on high, small sisters are multiple, sited, and supple. In apprehending Alexa's operations, we gain insight into how trust is generated and technologies insinuated within the everyday.

Suggested Citation (APA): Munn, L. (2019, October 2-5). "Alexa, Can I Trust You?": Small Sisters and Friendly Power. Paper presented at AoIR 2019: The 20th Annual Conference of the Association of Internet Researchers. Brisbane, Australia: AolR. Retrieved from http://spir.aoir.org. 


\section{AOR}

Selected Papers of \#AolR2019:

The $20^{\text {th }}$ Annual Conference of the Association of Internet Researchers Brisbane, Australia / 2-5 October 2019

\section{References}

Bohn, Dieter. "Amazon Says 100 Million Alexa Devices Have Been Sold — What's next?" The Verge, January 4, 2019.

https://www.theverge.com/2019/1/4/18168565/amazon-alexa-devices-how-many-soldnumber-100-million-dave-limp.

Han, Byung-Chul. Psychopolitics: Neoliberalism and New Technologies of Power. London: Verso Books, 2017.

Harcourt, Bernard. Exposed: Desire and Disobedience in the Digital Age. Cambridge, MA: Harvard University Press, 2015.

MacMillan, Douglas. "Amazon Says It Has Over 10,000 Employees Working on Alexa, Echo." Wall Street Journal, November 13, 2018, sec. Tech.

https://www.wsj.com/articles/amazon-says-it-has-over-10-000-employees-working-onalexa-echo-1542138284.

McGirt, Ellen. "Amazon's Echo Device Chief on the Risk of Alexa's Many Rewards." Fortune, July 17, 2018. http://fortune.com/2018/07/16/amazon-alexa-echo-toni-reid/. Purington, Amanda, Jessie G Taft, Shruti Sannon, Natalya N Bazarova, and Samuel Hardman

Taylor. "Alexa Is My New BFF: Social Roles, User Satisfaction, and Personification of the Amazon Echo." In Proceedings of the $2017 \mathrm{CHI}$ Conference Extended Abstracts on Human Factors in Computing Systems, 2853-2859. Denver: ACM, 2017.

Schwedel, Heather. "What Life With an Amazon Echo Is Like After the Novelty Wears Off." Slate Magazine, December 26, 2017. https://slate.com/technology/2017/12/whatlife-with-an-amazon-echo-is-like-after-the-novelty-wears-off.html.

Simonite, Tom. "Alexa Gives Amazon a Powerful Data Advantage." MIT Technology Review, January 18, 2017. https://www.technologyreview.com/s/603380/alexa-givesamazon-a-powerful-data-advantage/.

Suggested Citation (APA): Munn, L. (2019, October 2-5). "Alexa, Can I Trust You?": Small Sisters and Friendly Power. Paper presented at AoIR 2019: The 20th Annual Conference of the Association of Internet Researchers. Brisbane, Australia: AolR. Retrieved from http://spir.aoir.org. 


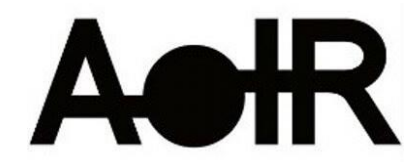

Selected Papers of \#AoIR2019:

The $20^{\text {th }}$ Annual Conference of the Association of Internet Researchers Brisbane, Australia / 2-5 October 2019

Turk, Victoria. "Home Invasion." New Scientist 232, no. 3104 (December 17, 2016): $16-$ 17. https://doi.org/10.1016/S0262-4079(16)32318-1.

Suggested Citation (APA): Munn, L. (2019, October 2-5). "Alexa, Can I Trust You?": Small Sisters and Friendly Power. Paper presented at AoIR 2019: The 20th Annual Conference of the Association of Internet Researchers. Brisbane, Australia: AolR. Retrieved from http://spir.aoir.org. 